\title{
"City size and functional specialization as factors of smart management: A case of Lviv Oblast, Ukraine"
}

\begin{tabular}{|c|c|}
\hline AUTHORS & $\begin{array}{l}\text { Roman Lozynskyy (D) } \\
\mathbb{R} \\
\text { Oleh Hrymak (D) } \\
\mathbb{R} \\
\text { Lesya Kushnir (D) } \\
\mathbb{R} \\
\text { Oksana Terletska (D) } \\
\mathbb{R} \\
\text { Myroslava Vovk (D) } \\
\mathbb{R}\end{array}$ \\
\hline ARTICLE INFO & $\begin{array}{l}\text { Roman Lozynskyy, Oleh Hrymak, Lesya Kushnir, Oksana Terletska and } \\
\text { Myroslava Vovk (2021). City size and functional specialization as factors of smart } \\
\text { management: A case of Lviv Oblast, Ukraine. Problems and Perspectives in } \\
\text { Management, 19(2), 384-397. doi:10.21511/ppm.19(2).2021.31 }\end{array}$ \\
\hline DOI & http://dx.doi.org/10.21511/ppm.19(2).2021.31 \\
\hline RELEASED ON & Monday, 28 June 2021 \\
\hline RECEIVED ON & Monday, 22 February 2021 \\
\hline ACCEPTED ON & Thursday, 10 June 2021 \\
\hline LICENSE & $\begin{array}{l}(c) E Y \\
\text { This work is licensed under a Creative Commons Attribution } 4.0 \text { International } \\
\text { License }\end{array}$ \\
\hline JOURNAL & "Problems and Perspectives in Management" \\
\hline ISSN PRINT & $1727-7051$ \\
\hline ISSN ONLINE & $1810-5467$ \\
\hline PUBLISHER & LLC "Consulting Publishing Company "Business Perspectives" \\
\hline FOUNDER & LLC "Consulting Publishing Company "Business Perspectives" \\
\hline
\end{tabular}

NUMBER OF REFERENCES

48

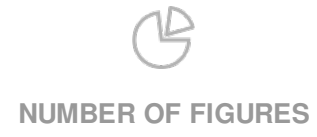

3
NUMBER OF TABLES

5

(C) The author(s) 2021. This publication is an open access article. 


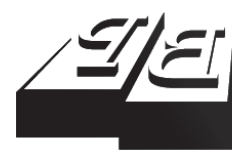

\section{BUSINESS PERSPECTIVES}

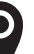

LLC "CPC "Business Perspectives" Hryhorii Skovoroda lane, 10, Sumy, 40022, Ukraine www.businessperspectives.org

Received on: 22 nd of February, 2021 Accepted on: $10^{\text {th }}$ of June, 2021 Published on: $28^{\text {th }}$ of June, 2021

(C) Roman Lozynskyy, Oleh Hrymak, Lesya Kushnir, Oksana Terletska, Myroslava Vovk, 2021

Roman Lozynskyy, Doctor of Geography, Professor, Head of the Department of Geography of Ukraine, Ivan Franko National University of Lviv, Ukraine. (Corresponding author)

Oleh Hrymak, Candidate of Economic Sciences, Associate Professor, Head of the Faculty of Economic and Management, Associate Professor of the Department of History of Ukraine, Economic Theory and Tourism, Stepan Gzhytskyi National University of Veterinary Medicine and Biotechnologies, Ukraine.

Lesya Kushnir, Candidate of Economic Sciences, Associate Professor, Head of the Department of History Ukraine, Economic Theory and Tourism, Stepan Gzhytskyi National University of Veterinary Medicine and Biotechnologies, Ukraine.

Oksana Terletska, Candidate of Geographical Sciences, Senior Lecturer of the Department of History of Ukraine, Economic Theory and Tourism, Stepan Gzhytskyi National University of Veterinary Medicine and Biotechnologies, Ukraine.

Myroslava Vovk, Candidate of Economic Sciences, Associate Professor Associate Professor of the Department of Management, Stepan Gzhytskyi National University of Veterinary Medicine and Biotechnologies, Ukraine.
Roman Lozynskyy (Ukraine), Oleh Hrymak (Ukraine), Lesya Kushnir (Ukraine), Oksana Terletska (Ukraine), Myroslava Vovk (Ukraine)

\section{CITY SIZE AND FUNCTIONAL SPECIALIZATION AS FACTORS OF SMART MANAGEMENT: A CASE OF LVIV OBLAST, UKRAINE}

\begin{abstract}
The process of understanding the factors that affect the implementation of smart management in cities is pivotal for using this concept to improve the well-being of the population. The goal of this study is to establish the specifics of the implementation of the smart management concept in cities with different sizes and functional specialization. 44 cities of Lviv Oblast (Ukraine) are selected for this goal. The main method was a content analysis of information sources related to the activities of local authorities. The most important indicators that reflect the development of various components of a smart city are analyzed. It is established that measures for the introduction of smart technologies are carried out in most cities of the Oblast (about 80\%). The leading cities are Lviv and Drohobych, among other cities are Boryslav, Truskavets, and Zolochiv. The share of cities with a high level of implementation of smart management technology is only $4 \%$. However, $56 \%$ of the total urban population lives in these cities. Other cities are the smallest cities that did not have the functions of district centers. The share of such cities is $20 \%$ but only $3 \%$ of the population inhabits them. Among the components of the smart city concept, e-government tools are being most actively developed, followed by energy efficiency measures. There is no direct relationship between the size of cities and the implementation of smart technologies. Smart technologies are most intensively implemented in cities focused on tourism development. Former industrial cities are less successful.
\end{abstract}

\section{Keywords smart initiatives, smart city, e-government, city, Lviv Oblast}

\section{JEL Classification $\quad$ M15, O32, R58}

\section{INTRODUCTION}

A typical feature of the development of the world's leading cities was the widespread use of the urban concept of smart management since the beginning of the XXI century. It is very close to the concept of a "smart city" - a city where the latest scientific advances, in particular, digital information and communication technologies are actively used to improve the quality of life. The differences between the two concepts are primarily that the first one ("smart management") is designed not only for cities but for local communities in general and adapted to the needs of local administration, and the second one ("smart city") focuses on the practical side, on specific technological solutions that are sold mostly in urban settlements.

Over the last decade, Europe and the world have developed many regulations related to the implementation of the concept of smart management, as well as approved several standards: ISO 37120, ISO 37122, ETSI, ITU 4901, ITU 4902, and SDG 11. They relate to the safety of residents, recycling of garbage, health care, public transport, urban lighting, etc. Smart technologies are becoming a crucial factor in the development of several critical activities on which modern society de- 
pends i.e., water, electricity and gas, food production, medicine, long-distance communications, public administration, waste collection, etc. The latest developments in the world related to the spread of the COVID-19 pandemic are further contributing to the accelerated use of smart city technologies. The popularity of the concept of smart management and administration is also constantly growing in Ukraine. Cities are actively implementing numerous smart technological solutions, creating and promoting smart city ratings. In Ukraine, the Kyiv Smart City Forum has been held in Kyiv annually since 2015 .

The process of understanding the factors that affect the implementation of smart management in cities is essential for using this concept to improve the well-being of the population. These factors are the level of economic development of cities, their size, functional type (specialization), geographical location, selected management strategies, etc.

The aim is to establish the specifics of the implementation of the smart management concept in cities of different sizes and functional specialization, and consider these factors while developing strategies and standards for smart cities.

\section{LITERATURE REVIEW}

The term smart city was firstly introduced in the United States, in the business environment of two corporations, IBM and CISCO. This was the name of the "ideal" automated city. In the 1990s, the term smart city first appeared in scientific publications in the United States, due to the concept of smart growth (Knaap \& Talen, 2005; Rosati \& Conti, 2016). It was developed in North America in the early 1990s during discussions by American urban planners about the foundations of a new urban policy (Burchell et al., 2000; Downs, 2005) that was in line with the ideas of new urbanism and sustainable development. However, the rapid development of the smart city concept and its implementation at the city in the field of policy and planning level began only around 2010 (Ahvenniemi et al., 2017; Masik \& Studzińska 2018). Currently, the issue of a smart city is being studied in close connection with sustainable development (Huovila et al., 2019). Reasonable growth is one of the key elements of European economic policy. It is included in the Europe 2020 document, which sets out EU strategic goals for rapid economic growth by reducing countries' public debt and social income inequality.

There are many different definitions of a smart city in the literature. OECD (2020) defines smart cities as "initiatives or approaches that effectively leverage digitalization to boost citizen well-being and deliver more efficient, sustainable and inclusive urban services and environments as part of a collaborative, multi-stakeholder". The issues of smart cities, smart growth, and smart management potentially include an infinite number of policies, innovations, and goals, which leads to a large number of different scientific publications. In fact, as of today, a smart city is an umbrella concept that scholars use to discuss the use of technology in the urban future (Jong et al., 2015).

Most studies about smart cities concern the technological aspect and the management side. Vanolo (2016) divided all studies related to the issue of smart cities into two directions: instrumental and critical ones. Representatives of the first direction show how smart technologies are used for urban development and how these technologies can be improved. Representatives of the second direction question the goals of the smart city agenda. In particular, it is mostly argued that the process of promoting smart management ideas hides private and corporate economic interests, especially the interests of large multinational companies (McFarlane \& Söderström, 2017; Viitanen \& Kingston, 2014). On the contrary, Viitanen and Kingston (2014), and Luque-Ayala and Marvin (2015) believed that the ideas of smart management are Universalist abstract ideas, a new urban utopianism of the $21^{\text {st }}$ century.

Kummitha and Crutzen (2017), and Masik and Studzińska (2018) identified four research trends (approaches, schools) within the smart city field: restrictive, reflective, rationalistic, and pragmatic. 
The restrictive trend is focused primarily on the development of advanced information and communication technologies. These technologies are a key tool that stimulates interaction between different actors in public life, as well as they are a driving force that makes cities smart (Calzada \& Cobo, 2015; Pilarczyk \& Górka, 2018). Angelidou (2015) supported the reflective trend and believed that the society itself (human resources in terms of human and social capital) is the driving force leading to the development of a smart city. The rationalist trend combines the two previous approaches and focuses on the development of local communities, which should be the main drivers of change (Neirotti et al. 2014). The critical trend states that smart cities should be considered mainly through the prism of organizational and administrative aspects.

There are many related concepts related to a smart city, for example, intelligent city, knowledge city, creative city, digital city, talented city (Zakrzewska-Półtorak, 2015, p. 284), connected city, entrepreneurial city, livable city, and pioneer city (Lombardi et al., 2012). There are different methodological approaches to the selection of the main components of smart cities. The most common is the synthetic approach - the allocation of six components: smart economy, smart environment, smart population, smart living, smart governance, and smart mobility (Albino et al., 2015; Sigalat-Signes et al., 2019).

An important methodological problem is still the choice of indicators that confirm the creation of a smart city. For example, N. Komninos and co-authors (Komninos et al., 2015) offered a set of 40 indicators, grouped into 4 categories: education and skills; knowledge and innovation institutions; digital infrastructure and e-services; and achievements related to innovation. Another important issue is the classification of smart cities. Taking into account the combination and interaction of components of a smart city, the size of cities, their financial resources, and some other features, OECD (2020) identified five approaches to the typology of smart cities: by the level of economic growth and status of a city, by smart urban innovations dimensions, by goals, and by spatial cluster analysis. Within each approach, several groups are distinguished.
In Ukraine, over the last 5 years, several detailed studies on smart city issues have appeared. In classical universities, it is mainly studied by economists and specialists in public administration, and less - by geographers. Specialists in technical sciences, architecture, and urban planning study smart cities in polytechnic universities. Several doctoral dissertations testify to the growing attention to the issue. Korepanov (2018) studied the methodological principles of statistical management of the development of "smart" sustainable cities in Ukraine. Dmytrenko (2018), and Dmytrenko and Chukut (2018) established the mechanisms of implementation of e-government at the local level. Boreiko and Teslyuk (2016), Boreiko, Teslyuk, Zelinskyy, and Berezsky (2017), and Boreiko, Teslyuk and Chorna (2017) dealt with issues of information technology of data processing concerning the parameters of public transport passenger flow. Pozdniakova (2017, 2018), Matyushenko and Pozdnyakova (2016), and Poliakova and Pozdniakova (2019) studied various implementation aspects of smart city technologies in Ukraine. Besides, Dykan et al. (2019) focused on the implementation of the smart city concept in Ukraine. Pavlikha and Kolomechiuk (2018) studied the establishment of patterns and dynamics of the formation of smart cities in the world and Ukraine.

An important source of current information in the implementation of smart city technologies in different cities and different directions. There are national Internet portals "Urban Development Platform", "Skyscraper", and "Mistosite", as well as specialized pages created by the authorities of leading cities, which inform about their success in the implementation of smart city technologies, such as the Kyiv Smart City.

A review of publications concerning smart city issues showed a small number of studies focused on the impact of such factors as city size and functional specialization (especially concerning countries in transit towards market economies, such as Ukraine and its Oblasts) on smart management. To fill this gap, the specific purpose of this study is to establish the current state of implementation of the concept of smart management in Ukraine on the example of the different cities in Lviv Oblast and to identify the impact of the mentioned fac- 
tors. To reveal it, the following research objectives were set: a) analyze the regional dimension of the implementation of the concept, i.e. not for one or more cities, but for their whole set, highlighting possible territorial features; b) establish the role of the concept in the activities of local authorities, i.e. to identify what it stands for, as a well-thought-out city policy or as a poorly defined agenda; c) describe the features of the implementation of the concept in cities with a different number of inhabitants and functional specialization.

\section{METHODOLOGY}

Many indicators reflect the state, stages, and features of smart technologies introduction. In addition, they have different values. To reduce the complexity of the study and not to calculate integrated indices for all 44 cities of Lviv Oblast, the study was divided into stages, with a sequential selection of groups of cities. The main idea was to conduct the content analysis of the activities of the relevant local authorities (city councils) at all stages. In particular, the official and unofficial webpages of city councils, web portals to which they are connected, regulatory documents, and other sources of information were analyzed (Table 1).

At the first stage, the leading cities were established. These are cities that are present in international rankings related to smart management (IMD Smart City Index, Innovation Cities Index, and Cities in Motion Index). In addition, they are winners of national competitions of smart cities (Smart Cities Awards Ukraine within the Kyiv Smart City Forum) and are present in the transparency ranking of Ukrainian cities (defined by Transparency International Ukraine with the support of the European Union and the UNDP project "Civil Society for Democracy and Human Rights in Ukraine").
In the second stage, outsider cities were identified. Content analysis of the official webpages of cities (local governments - city councils, and in some cases - webpages of united territorial communities) was performed. The pages of cities contain information about the introduction of smart management technologies. As a rule, there are e-government tools (e-petitions, public budget, population surveys, etc.), links to city web cameras, and electronic doctor appointments. In addition, normative documents (development strategies or programs, decisions, and resolutions) are posted, from which one can learn about the activities of the authorities on the introduction of smart technologies. There are cities whose official webpages contain only the most general information about the city, its history, telephone numbers of city services, photos, and breaking news. These pages are usually not interactive and relate to city outsiders in implementing smart management technologies.

At the third stage, the cities were graded (except for the already recognized leaders and outsiders) according to the level of implementation of smart management technologies. The peculiarities of their use of e-government tools (e-democracy) were analyzed with this aim. Four basic elements are included: e-petitions, public budget (participation budget), open city (city statistics database), and public consultations (polls). Additionally, an electronic doctor appointment, online broadcasts of city council sessions, the availability of an open data portal, and the city helper bot were taken into account as well. All cities are divided into three groups according to the level of implementation of various elements of e-government: high, medium, and low.

Then, in the fourth stage, an additional point evaluation of cities in which the level of implementation of e-government technologies is above average was conducted to determine the best of them.

Table 1. Research stages and indicators used

\begin{tabular}{|c|c|c|}
\hline Stage & Task & Indicators \\
\hline I & Identification of leader cities & $\begin{array}{l}\text { International rankings related to smart management, national rankings, and contests of } \\
\text { smart cities }\end{array}$ \\
\hline II & $\begin{array}{l}\text { Identification of outsider } \\
\text { cities }\end{array}$ & Content analysis of official webpages of cities \\
\hline III & $\begin{array}{l}\text { Classification of cities with } \\
\text { an average level }\end{array}$ & $\begin{array}{l}\text { Analysis of e-government tools: e-petitions, public budget (participation budget), open } \\
\text { city (city statistics database), and public consultations (polls) }\end{array}$ \\
\hline IV & $\begin{array}{l}\text { Clarification of the position } \\
\text { of cities }\end{array}$ & $\begin{array}{l}\text { Point evaluation: city electronic applications, CCTV cameras, GPRS-trackers of transport, } \\
\text { program documents, solar energy, and energy-saving }\end{array}$ \\
\hline
\end{tabular}


Table 2. Distribution of cities of Lviv Oblast by population

Source: State Statistics Service of Ukraine (2021).

\begin{tabular}{c|c|c:c}
\hline No. & City type & $\begin{array}{c}\text { Thousands of } \\
\text { people }\end{array}$ & Cities \\
\hline 1 & Large & Over 100 & Lviv \\
\hline 2 & Average & $50-99,9$ & Drohobych, Stryi, Chervonohrad \\
\hline 3 & Small & $10-49,9$ & $\begin{array}{c}\text { Boryslav, Brody, Gorodok, Dublyany, Kamyanka-Buska, Mykolaiv, Novoyavorivsk, Novy Rozdil, } \\
\text { Sambir, Sokal, Sosnivka, Stebnyk, Truskavets, Vynnyk, Yavoriv, Zhydachiv, Zhovkva, Zolochiv }\end{array}$ \\
& Very small & Up to 10 & $\begin{array}{c}\text { Belz, Bibrka, Busk, Velyki Mosty, Hlyniany, Dobromyl, Komarno, Morshyn, Mostyska, Novy } \\
\text { Kalyniv, Peremyshliany, Pustomyty, Rava-Ruska, Radekhiv, Rudky, Skole, Stary Sambir, Sudova } \\
\text { Vyshnia, Turka, Uhniv, Khyriv, Khodoriv }\end{array}$ \\
\hline 4
\end{tabular}

For this purpose, in addition to e-government indicators (based on the data of the third stage), information on the implementation of smart solutions in the transport and energy sectors, in the safety of residents, and in management decisions is involved. In particular, information on:

- city electronic applications (availability, operation, occupancy, specialized programs, such as electronic application of the city taxi service) - up to 3 points;

- CCTV cameras (number, operation, online surveillance cameras, analytical smart cameras with license plate recognition) - up to 3 points;

- GPRS-trackers of transport (availability, operation) - up to 3 points;

- program documents (availability of items on smart management in strategies, development programs, decisions of the city council, etc.) up to 3 points;

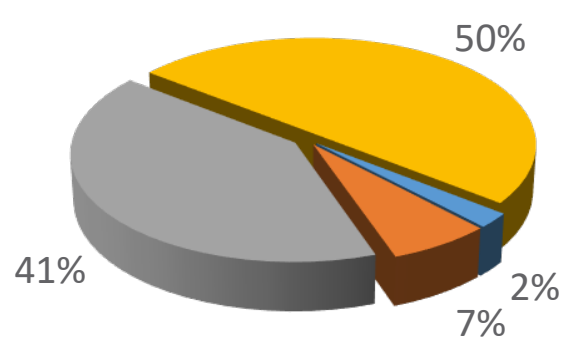

- large average asmall $\square$ very small
- solar energy and energy-saving (solar power plants, solar panels, panels placed on roofs and ground, their capacity, energy-saving technologies, charging stations for electric vehicles) - up to 5 points. The sources for this data were Energo (2020) - about solar energy sources, and Ecocars (2020) - about charging stations for electric cars.

Classification of cities by the level of implementation of smart technologies makes it possible to analyze the impact of the size and functional type of cities.

\section{RESULTS}

There were 44 cities in Lviv Oblast at the beginning of 2020. In terms of their number, the Oblast is the second only to Donetsk Oblast. This number of cities is caused by historical factors, namely the transition of Western Ukraine to the USSR in 1939. Historical factors were often the main factor in giving a settlement the status of a city, compared

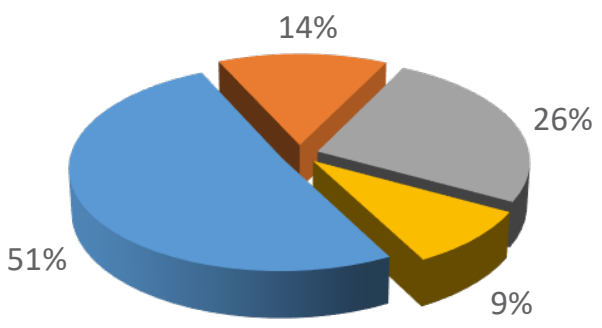

- large average small very small

Figure 1. Cities of Lviv Oblast, by type (left) and population (right) 
to the factors of population and functional type. Most of the small towns of the Oblast are ancient historical settlements, which in the XV-XVIII centuries had the Magdeburg rights. Despite the small number of inhabitants, they have preserved urban development and urban lifestyle. There are all types of cities in the Oblast by population, except for millionaire cities, but more than $90 \%$ are small towns (Table 12). In total, about 1,430,000 residents of the Oblast live in cities, of which $51 \%$ - in Lviv, 14\% - in medium-sized cities, and 35\% in small and very small cities (Figure 1).

At the first stage, the establishment of leaders in the implementation of smart management technologies, according to the criteria of the presence in international indices and the presence of national awards, two cities were identified - Lviv and Drohobych. Lviv is the only city included in international indices related to the introduction of smart technologies. In 2019, Lviv and the capital of Ukraine, Kyiv, entered the top 10 cities in the world in fDi's Smart Locations of the Future 2019/20 ranking, in the cost effectiveness category (Davis, 2020). Lviv took the $8^{\text {th }}$ place, and Kyiv the $5^{\text {th }}$.

Lviv has been present in the Innovation Cities ${ }^{\text {Txt }}$ Index for many years, which is calculated by the Australian innovation agency 2thinknow (2020). The city first appeared in these indices in 20122013. Its highest position in the global ranking was in 2014 - the $350^{\text {th }}$ place (Table 3). Unfortunately, in recent years, the total number of points received by the city, as well as its place, is constantly declining. The reason for this is not the slowdown in the introduction of smart technologies, but the outpacing development of other cities, especially in the Asia-Pacific region.

Lviv has won five times various nominations at the Kyiv Smart City Forum in the last three years: in 2018 - in the nomination "City of Startups"; in 2019 the transport model of Lviv was recognized as the best in the country; in 2020 - in three nominations at once: "The best ecological city", "The best architectural city", and "The best mobile city".

Several smart projects have been implemented in Lviv. For example, the largest in the Western Ukraine facade solar power plant with a capacity of up to 200 thousand $\mathrm{kWh}$ per year is located in the city. In 2019, it was installed on one of the city office buildings.

Apart from Lviv, only Drohobych won the Kyiv Smart City Forum twice. In 2019, it won the nomination "Open Innovation City", in 2018 - "Open City". Drohobych greatest success in implementing smart technologies is related to e-government and open data. Back in 2016, the implementation of the project "Drohobych - Smart City" started. The city created an open data portal, which houses more than 220 data sets. Other areas of smart management are being elaborated as well.

In addition, in 2018 and 2019, Drohobych took first place in the ranking of transparency of Ukrainian cities, which is determined by Transparency International Ukraine $(2018,2019)$.

Table 3. Lviv in the ratings of Australian innovation agency 2thinknow

Source: 2thinknow (2020).

\begin{tabular}{|c|c|c|c|c|}
\hline $\mathbf{N}$ & Year & Points & Index names & Place \\
\hline \multirow{2}{*}{1} & \multirow{2}{*}{2019} & \multirow{2}{*}{27} & Innovation Cities ${ }^{\mathrm{TM}}$ Index 2019: Global & 470 \\
\hline & & & Innovation Cities ${ }^{\top M}$ Index 2019: Emerging & 37 \\
\hline \multirow{2}{*}{2} & \multirow{2}{*}{2018} & \multirow{2}{*}{28} & Innovation Cities $^{\text {TM }}$ Index 2019: Global & 468 \\
\hline & & & Innovation Cities ${ }^{\mathrm{TM}}$ Index 2019: Emerging & 34 \\
\hline \multirow{2}{*}{3} & \multirow{2}{*}{ 2016-2017 } & \multirow{2}{*}{30} & Innovation Cities ${ }^{\text {TM }}$ Index 2016-2017: Global & 453 \\
\hline & & & Innovation Cities ${ }^{\mathrm{TM}}$ Index 2016-2017: Emerging & 27 \\
\hline \multirow{2}{*}{4} & \multirow{2}{*}{2015} & \multirow{2}{*}{37} & Innovation Cities ${ }^{\mathrm{TM}}$ Index 2015: Global & 371 \\
\hline & & & Innovation Cities ${ }^{\mathrm{TM}}$ Index 2015: Emerging & 16 \\
\hline \multirow{3}{*}{5} & \multirow{3}{*}{2014} & \multirow{3}{*}{38} & Innovation Cities ${ }^{\mathrm{TM}}$ Index 2014: Global & 350 \\
\hline & & & Innovation Cities ${ }^{\mathrm{TM}}$ Index 2014: Emerging & 12 \\
\hline & & & Innovation Cities ${ }^{T M}$ Index 2014: Eurasia & 2 \\
\hline \multirow{2}{*}{6} & \multirow{2}{*}{ 2012-2013 } & \multirow{2}{*}{42} & Innovation Cities ${ }^{\mathrm{TM}}$ Global Index 2012-2013 & 5 \\
\hline & & & Innovation Cities ${ }^{\mathrm{TM}}$ Emerging Index 2012-2013 & - \\
\hline
\end{tabular}


In 2017, Lviv was in the first place. In general, the indicators of the cities of Lviv Oblast in 2019 were as follows: Drohobych - 79.1 points, Lviv - 73.7, Chervonohrad - 38.5, Sambir - 25.7, Stryy - 20.1 points. The average level in Ukraine was 45.7 points.

At the second stage of the selection of outsider cities, content analysis of official websites was carried out. It turned out that in Lviv Oblast there are more than a dozen cities, which official pages contain only the most general information about the settlements: Belz, Bibrka, Busk, Velyki Mosty, Dobromyl, Komarno, Novy Kalyniv, Peremyshlyany, Rava-Ruska, Sosnivka, and Uhniv. These are cities that were not the administrative centers of the districts, the smallest in the population (up to 5 thousand inhabitants), as well as they are declining settlements due to their inconvenient geographical location. One city, Uhniv, does not even have an official website. It is the smallest city in Ukraine, with less than 1,000 inhabitants.

At the third stage, cities were divided (except for already established leaders and outsiders) according to the degree of implementation of e-democracy technologies. It turned out that in the cities of the Oblast the leadership chose different ways of its implementation: the use of the web resource "Single platform of local e-democracy" (abbreviated - e-DEM); use of the e-government and democracy web resource "Smart City"; development of own smart governance tools; others (electronic petitions miskrada.org.ua, petitions of the Association of Ukrainian Cities, etc.). The most effective in cities was the use of web platform e-DEM. It allows the introduction of 4 services: local petitions, public budget, open city, and public consultations (polls). As of summer 2020, e-DEM was used by 14 small towns of Lviv Oblast: Boryslav, Brody, Gorodok, Zhovkva, Kamyanka-Buzka, Morshyn, Novy Rozdil, Novoyavorivsk, Pustomyty, Rudky, Sambir, Stryy, Skole, Truskavets, and Yavoriv. However, only Brody population is using all four services. The most popular service was "local petitions" - it was used in 10 cities, the second place held the service "public budget" - 9 cities, "open city" - 5 cities, public consultations (polls) - 3 cities. In some cities, the use of e-DEM has proved ineffective due to low population activity. The Smart City web platform has significantly more services than e-DEM, only 10 of them, and all cities in Ukraine are automatically connected to four. However, the use of this platform in small towns of Lviv Oblast has proved to be generally ineffective. In 2016, the year the project began, only three small towns used it: Zhydachiv, Zolochiv, and Truskavets. However, in 2016-2017, only residents of Zhydachiv and Truskavets used this platform. The following cities have developed and now use their e-government tools: Chervonohrad, Sokal, Stary Sambir, Sudova Vyshnya, Turka, Khyriv, and Khodoriv. Unfortunately, for the most part, they do not work properly in these cities. Usually, only the petition service is popular, less often - the public budget.

In addition, at this stage it was discovered that there is a certain category of cities, in which the "underdevelopment" of their tools of e-democracy is due to their special status - these were cities that were subordinated to cities of regional importance (Vynnyky, and Stebnyk). These cities used the electronic tools of the cities to which they were subject. Therefore, they are classified as a group of medium-level cities implementing smart solutions.

At the fourth stage, by scoring, it was found that among the cities with an average level of smart management technology are Boryslav, Truskavets and Zolochiv stand out, lagging behind Chervonograd, Brody, Zhovkva, Sambir, Sokal, and Stryy (Table 4). The most successful cities are in the introduction of energy-saving technologies, e-government, and the installation of cameras (Figure 3).

Boryslav achieved success in implementing smart city technologies among small towns in Lviv Oblast. In addition to the web platform e-DEM, an electronic doctor appointment has been introduced, an electronic application has been developed for a smartphone, and GPS navigation of public transport traffic has been introduced. In addition, Boryslav City Council has begun work on the implementation of the project "Boryslav Smart City". The first step in this direction was the creation of a working group to develop the project in July 2019. There are also two solar power plants.

An electronic city application was created and GPS navigation of public transport traffic was introduced in Truskavets as well. Much of the 


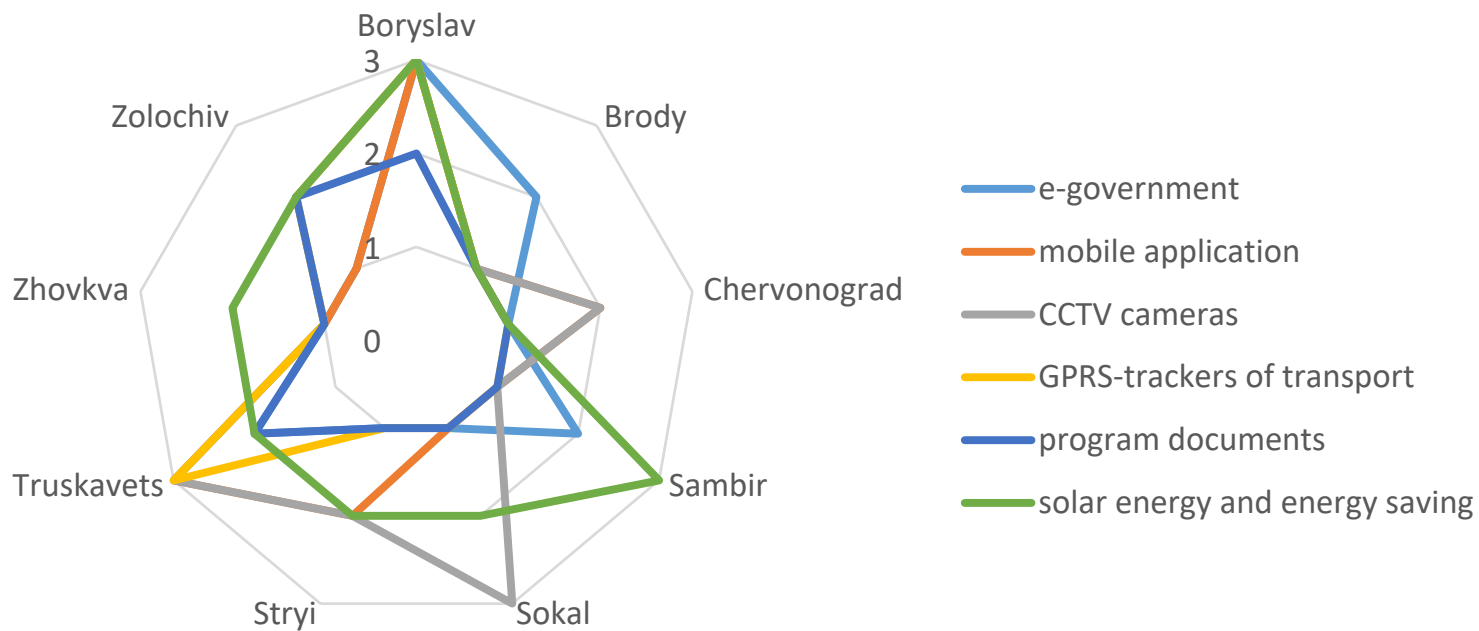

Figure 2. Development of smart technologies in the cities of Lviv Oblast

Table 4. Indices of cities in Lviv Oblast by the level of implementation of smart management technologies

\begin{tabular}{|c|c|c|c|c|c|c|c|}
\hline City & $\begin{array}{l}\text { e-gover- } \\
\text { nment }\end{array}$ & $\begin{array}{c}\text { Mobile } \\
\text { application }\end{array}$ & $\begin{array}{c}\text { CCTV } \\
\text { cameras }\end{array}$ & $\begin{array}{c}\text { GPRS-trackers } \\
\text { of transport }\end{array}$ & $\begin{array}{c}\text { Program } \\
\text { documents }\end{array}$ & $\begin{array}{c}\text { Solar energy } \\
\text { and energy } \\
\text { saving }\end{array}$ & Total \\
\hline Boryslav & 3 & 3 & 3 & 3 & 2 & 3 & 17 \\
\hline Brody & 2 & 1 & 1 & 1 & 1 & 1 & 7 \\
\hline Chervonograd & 1 & 2 & 2 & 1 & 1 & 1 & 8 \\
\hline Sambir & 2 & 1 & 1 & 1 & 1 & 3 & 9 \\
\hline Sokal & 1 & 1 & 3 & 1 & 1 & 2 & 9 \\
\hline Stryi & 1 & 2 & 2 & 1 & 1 & 2 & 9 \\
\hline Truskavets & 2 & 3 & 3 & 3 & 2 & 2 & 15 \\
\hline Zhovkva & 1 & 1 & 1 & 1 & 1 & 2 & 7 \\
\hline Zolochiv & 1 & 1 & 2 & 2 & 2 & 2 & 10 \\
\hline
\end{tabular}

smart solutions in this city are private initiatives because the city is a famous spa resort; there are many high-level private health facilities. Zolochiv is the city of the region, distinguished by smart initiatives as well. Three micro-projects were implemented in 2017: installation of electronic touch kiosks; construction of a smart street (installation of benches with built-in solar panels and bollards); and installation of video surveillance cameras.

An important prerequisite for the implementation of the smart city concept was to improve the

Table 5. Classification of cities in Lviv Oblast according to the level of implementation of smart solutions

Source: Authors' elaboration.

\begin{tabular}{|c|c|c|}
\hline No. & Group of cities & Cities \\
\hline 1 & Leaders - the international level & Lviv \\
\hline 2 & Leaders - the national level & Drohobych \\
\hline 3 & Level above average & Boryslav, Truskavets, Zolochiv \\
\hline 4 & Average & Sambir, Sokal, Stryi, Chervonohrad, Brody, Zhovkva, \\
\hline 5 & Level below average & Gorodok, Kamyanka-Buzka, Novoyavorivsk, Novy Rozdil, Stebnyk, Vynnyky, Yavoriv \\
\hline 6 & Low level & $\begin{array}{c}\text { Busk, Glynyany, Dublyany, Khodoriv, Morshyn, Mostyska, Mykolaiv, Novy Kalyniv, } \\
\text { Pustomyty, Radekhiv, Rava Ruska, Rudky, Skole, Sosnivka, Stary Sambir, Sudova } \\
\text { Vyshnya, Turka, Zhydachiv }\end{array}$ \\
\hline 7 & $\begin{array}{l}\text { Cities are outsiders, very low or no } \\
\text { implementation }\end{array}$ & $\begin{array}{c}\text { Belz, Bibrka, Dobromil, Khyriv, Komarno, Novy Kalyniv, Peremyshlyany, Rava-Ruska, } \\
\text { Velyki Mosty, Uhniv }\end{array}$ \\
\hline
\end{tabular}



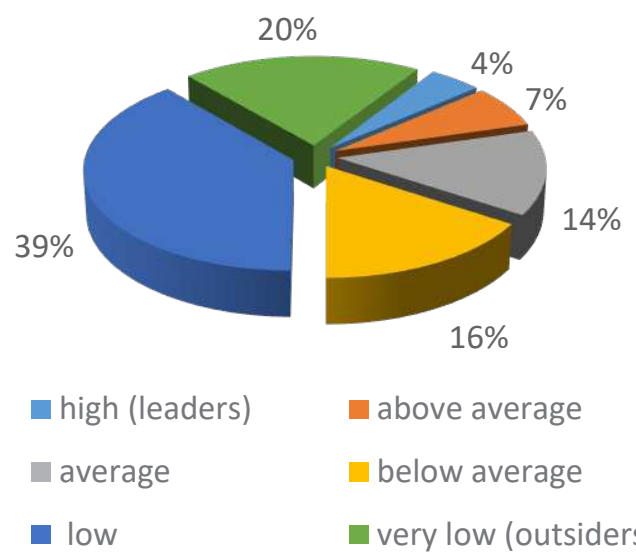

above average

below average

very low (outsiders)
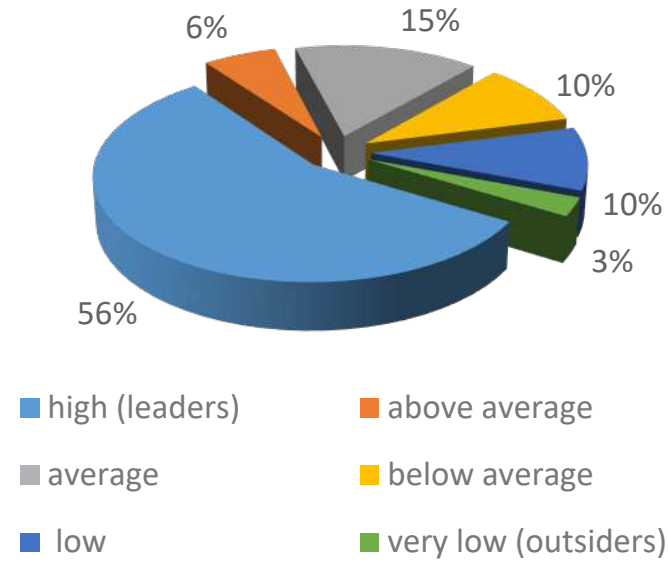

Figure 3. The level of development of smart city technologies in the cities of Lviv Oblast, by type (left) and population (right)

awareness of local authorities about its elements and ways of implementation. The educational projects of the German-Ukrainian program "Kyiv Dialogue" in 2018 were implemented in several cities. The workshop "Smart City - a project that changes cities" took place in Sambir. Three events took place in Brody within the project "We Build Smart Cities - from discussion to implementation".

In total, according to the level of implementation of smart technologies in Lviv Oblast, 7 groups of cities have been identified (Table 5, Figure 4).

Summing up the results of grouping cities, it is important to mention that in almost $80 \%$ of cities of Lviv Oblast certain smart initiatives are implemented. Even in cities that are included in the group with a low level of implementation of smart management, there are interesting solutions. For example, in Pustomyty, in March 2019, a "solar" or "smart" tree was installed in the central park - a structure with solar panels, which provides free charging of mobile devices, tablets, and laptops. In Busk, in the process of implementing "smart economy" technologies, a farmer from the Netherlands, Michael Honders, founded Galicia Greenery, a company that grows various types of lettuce using the method of dry hydroponics, a process completely controlled by a computer. Popular smart initiatives, which are often implemented in small towns of the Oblast, also include smart street lighting and the expansion of a free Wi-Fi network.
In some cities, the introduction of the smart city concept is enshrined in development strategies and plans. In Hlynyany, it was included in the "Action Plan for Sustainable Energy Development of Hlynyany for 2014-2019" as a strategic priority. In the "Stary Sambir Development Strategy for 2017-2020", participation in the "Smart City" network is recognized as one of the strategic goals.

\section{DISCUSSION}

A smart city is one of the most popular practice-oriented concepts in urban planning; its components have been actively implemented in Ukraine in recent years. The study of the experience of the cities in Lviv Oblast gives grounds to assert that the introduction of smart technologies in Ukraine is becoming ubiquitous. About $80 \%$ of cities in the Oblast are taking steps in this direction, and this share will continue to grow. However, in most cities of Lviv Oblast, the issue of smart management has not reached the level of the overall strategy. This confirms the findings of scholars that this concept is now understood more as a framework document or as a guide to action.

The introduction of smart city technologies is most active in large (over 100 thousand inhabitants) and medium (50-100 thousand) cities in terms of population. In small towns, due to objective circumstances, it is difficult to implement all the components of the smart city concept. However, 
even in them, local authorities are expanding the use of information technology in the practice of city government. However, there is no clear relationship between the level of implementation of smart city technologies and the size (population) of cities. It is important to say that only in the group of the smallest cities - up to 10 thousand - there are growing difficulties with the introduction of smart technologies, in particular, the tools of e-democracy. It is worth mentioning critical population, starting from which to implement some components of a smart city is no longer appropriate.

The issue of smart management and the development of tourism in cities deserves a separate discussion. There are mostly tourist cities in the top ten smart cities of Lviv Oblast. Lviv and Truskavets have long been known tourist centers in Europe. Zolochiv is a center of excursion tourism associated with visiting the castles of the "Golden Horseshoe Tour of Lviv". The city has been trying to create new tourist spaces in the city to increase the length of stay of tourists recently. The program of reconstruction of the central part of the city is realized for this purpose. Drohobych is known as an industrial city, but the activities of the city authorities in recent years are aimed at the development of tourism as one of the leading areas of the city economy. The situation is the same in Boryslav. One is trying to develop industrial tourism in this city. Therefore, ski lifts have been built in the neighborhoods. A famous sightseeing center is Zhovkva, built on the concept of "ideal cities" of the Renaissance.

The highest level of development of smart technologies in tourist cities is due to the specifics of the tourist product. Tourists live in an unfamiliar city for some time, which determines their additional needs that can be realized by smart management tools. Smart technologies contribute to a better acquaintance of the city by tourists, solve their safety issues, and increase their mobility.

Accordingly, tourism promotes smart technologies in transport, the creation of various mobile applications that would facilitate tourist orientation in the city, the development of bicycle rental, and improves street lighting. In addition, the use of smart technologies increases the tourist attractiveness of the city. Benches with solar panels and the ability to charge a smartphone, smart lighting systems, and smart public spaces form a positive image of the city in the eyes of tourists, and at the same time promote re-visiting. Therefore, tourist cities should continue to anticipate the advanced development of smart management technologies once the effects of the COVID-19 pandemic are overcome and tourist flows resume.

Less active is the use of smart technologies in the socalled industrial cities: Chervonohrad, Sosnivka, Stebnyk, Novy Rozdil, and Novoyavorivsk. However, the reason is that they have been industrial centers for a long time, but not nowadays (except for Chervonohrad, where several mines are still functioning). These are depressed settlements, due to the previous closure of city-forming industrial enterprises in them.

In terms of the territory, the cities of Precarpathia are better represented in terms of the level of introduction of smart technologies among the cities of the Oblast. It is worth mentioning the tourist orientation of the urban economy and the positive example of Drohobych, which government is purposefully developing smart management technologies.

The topical issue for the smallest cities of Lviv Oblast is the implementation of components of a slightly different from smart city, a model for implementing smart solutions, known as a smart village. According to it, the primary tasks of smart management are the automation of local councils for bookkeeping, statistical accounting of land, real estate, transport, etc., as well as automation (separately) of offices that provided services related to birth registration, marital status, and migration. The development of convenient electronic tools for all procedures and rules related to budget execution, creation of databases (land cadaster, construction cadaster, voter database, etc.) is also crucial. Important aspects of the introduction of smart technologies under this concept are also the process of increasing the availability of banking services, increasing the share of non-cash payment methods, and, respectively, the introduction of non-cash infrastructure.

Numerous difficulties with the implementation of smart solutions are common in the cities of Lviv 
Oblast, as well as in other regions and countries. This problem has been repeatedly noted by experts (Winkowska et al., 2018, p. 71). Many management decisions regarding smart cities are not implemented in the practice of city management. Unsatisfactory operation of developed mobile applications, installed surveillance cameras, GPRStrackers on transport, and low efficiency of solar power plants is a common phenomenon. Another problem is the imperfection of the legal regulation of certain aspects of the introduction of smart city technology. As a result, for example, in Lviv, the roof solar power plant installed in 2018 for the first time at one of the municipal secondary schools did not work. The reason was that the existing national regulatory framework did not allow the school to sell surplus electricity.

In general, the active development of smart infrastructure requires large investments, and indirectly these investments are made by the citizens themselves, as the funds are taken from their taxes.

\section{CONCLUSION}

While the importance of the cities size and functional specialization in the implementation of smart management strategies is well known, establishing the role of these factors requires further studies.

In Lviv Oblast (Ukraine), the two largest cities, Lviv and Drohobych, are leaders in the introduction of smart technologies. The reason for its leadership is bigger opportunities for large cities, larger budgets, and a purposeful policy of local authorities to introduce smart technologies. However, the relationship between the size of cities and the level of implementation of smart technologies is not that noticeable. Among the smaller cities, Truskavets, Boryslav, and Zolochiv have a high level of implementation of smart solutions too. Outsiders are the smallest cities, with a population of up to 10 thousand, and especially - up to 5 thousand inhabitants. However, even in such cities, there are successful examples of smart solutions or at least declarations of intent.

The introduction of smart technologies is influenced by its regional specifics - a high level of tourism development. The best development of smart-city technologies in tourist cities is due to the peculiarity of the sale of a tourist product, namely, the fact that tourists live for some time in an unfamiliar city. This means that their additional needs allow implementing the concepts of smart management. No peculiarities in the introduction of smart city technologies in the border settlements with Poland have been identified, although one could expect more active borrowing of innovations from them. Smart solutions are insufficiently implemented in industrial cities.

To conclude, it is crucial to mention that the introduction of smart technologies in Ukraine is becoming ubiquitous, based on the study of the experience of the cities in Lviv Oblast. However, except for individual cities, for the most part, this process is not a well-thought-out city policy, but rather a set of measures of varying degrees of interconnectedness, or a weak agenda for the coming years. Further research should focus on the development of practical recommendations for cities of different types, a more detailed analysis of the development of individual components of a smart city in the Oblast, a comparative analysis with cities in other Oblasts of Ukraine and neighboring countries, especially that are situated on the borders with Poland.

\section{AUTHOR CONTRIBUTIONS}

Conceptualization: Roman Lozynskyy.

Data curation: Roman Lozynskyy, Oleh Hrymak, Oksana Terletska .

Formal analysis: Roman Lozynskyy, Lesya Kushnir.

Investigation: Oleh Hrymak, Myroslava Vovk.

Methodology: Roman Lozynskyy. 
Project administration: Roman Lozynskyy, Lesya Kushnir.

Supervision: Roman Lozynskyy, Oksana Terletska.

Validation: Oleh Hrymak, Myroslava Vovk.

Visualization: Oksana Terletska, Myroslava Vovk.

Writing - original draft: Roman Lozynskyy, Oleh Hrymak, Lesya Kushnir.

Writing - review \& editing: Roman Lozynskyy, Lesya Kushnir, Oksana Terletska, Myroslava Vovk.

\section{REFERENCES}

1. 2thinknow. (2020). Innovation Cities $^{\text {Th }}$ Index. Retrieved from https://2thinknow.com/information/innovation-programs/ innovation-cities.

2. Ahvenniemi, H., Huovila, A., Pinto-Seppa, I., \& Airaksinen, M. (2017). What are the differences between sustainable and smart cities? Cities, 60, 234-245. Retrieved from https://cris.vtt.fi/en/publications/what-are-the-differencesbetween-sustainable-and-smartcities

3. Albino, V., Berardi, U., \& Dangelico, R. M. (2015). Smart Cities: Definitions, Dimensions, Performance, and Initiatives. Journal of Urban Technology, 22(1), 3-21. https://doi.org/10.1080/10630732. 2014.942092

4. Angelidou, M. (2015). Smart cities: A conjecture of four forces. Cities, 47, 95-106. https://doi. org/10.1016/j.cities.2015.05.004

5. Boreiko, O., \& Teslyuk, V. (2016). Developing a controller for registering passenger flow of public transport for the "smart" city system. Eastern-European Journal of Enterprise Technologies, 3(84), 4046. https://doi.org/10.15587/1729 4061.2016.84143

6. Boreiko, O., Teslyuk, V., \& Chorna, I. (2017). Analysis and prospects of smart city technology development. Innovative education as a constituent part of the smart city. Series of monographs, Faculty of Architecture, Civil Engineering and Applied Arts Katowice School of Technology, 14, 60-70.

7. Boreiko, O., Teslyuk, V., Zelinskyy, A., \& Berezsky, O. (2017). Development of models and means of the server part of the system for passenger traffic registration of public transport in the "smart" city. Eastern-European Journal of Enterprise Technologies, 1(2(85), 40-47. https://doi.org/10.15587/17294061.2017.92831

8. Burchell, R. W., Listokin, D., \& Galley, C. C. (2000). Smart growth: More than a ghost of urban policy past, less than a bold new horizon. Housing Policy Debate, 11(4), 821-879. https://doi.or g/10.1080/10511482.2000.9521390

9. Calzada, I., \& Cobo, C. (2015). Unplugging: Deconstructing the Smart City. Journal of Urban Technology, 22(1), 23-43. Retrieved from https://www.compas.ox.ac. uk/2015/unplugging-deconstructing-the-smart-city/

10. Davis, N. (2020). Singapore tops fDi's Smart Locations of the Future 2019/20 ranking. fDi Intelligence. Retrieved from https://www.fdiintelligence.com/article/74562

11. Dmytrenko, V. (2016). Specificities of E-Governance Local Implementation in Ukraine. Public Policy and Economic Development, 9(13), 84-93. Retrieved from https://idu. at.ua/publpol/v13.pdf

12. Dmytrenko, V., \& Chukut, S. (2016). Smart-siti chy elektronne misto: suchasni pidkhody do rozuminnia vprovadzhennia e-uriaduvannia na mistsevomu rivni [Smart city or e-city: modern approaches to understanding the implementation of e-government at the local level]. Investytsii: praktyka ta dosvid - Investments: practice and experience, 13, 89-93. (In Ukrainian). Retrieved from http://www.irbis-nbuv.gov.ua/ cgi-bin/irbis_nbuv/cgiirbis_64.ex e?I21DBN=LINK\&P21DBN=U $J R N \& Z 21 I D=\& S 21 R E F=10 \& S 2$ $1 \mathrm{CNR}=20 \& \mathrm{~S} 21 \mathrm{STN}=1 \& \mathrm{~S} 21 \mathrm{FM}$ $\mathrm{T}=\mathrm{ASP} \_$meta\&C21COM=S\&2_

\section{S21P03=FILA = \&2 \\ S21STR=ipd_2016_13_17}

13. Downs, A. (2005). Smart Growth: Why We Discuss It More than We Do It. Journal of the American Planning Association, 71(4), 367-378. https://doi. org/10.1080/01944360508976707

14. Dykan V., Ieromyna M., Storozhylova U., \& Bilous L. (2019). Implementation of Smart City Concept in Ukraine. SHS Web of Conferences, 67(15). Retrieved from https://www.researchgate.net/ publication/336561175_Implementation_of_Smart_City_Concept_in_Ukraine

15. Ecocars. (2020). Karta elektrozapravok Ukrainy [Map of electric vehicle charging station in Ukraine]. (In Ukrainian). Retrieved from https://ecocars.in.ua/elektrozapravky

16. e-DEM. (2020). The only platform for local e-democracy. (In Ukrainian). Retrieved from https://edem.ua/about_us

17. Energo. (2020). Obiekty VDE [Renewable energy facilities]. (In Ukrainian). Retrieved from https://www.energo.ua/ua/assets

18. Huovila, A., Bosch, P., \& Airaksinen, M. (2019). Comparative analysis of standardized indicators for Smart sustainable cities: What indicators and standards to use and when? Cities, 89, 141-153. https://doi.org/10.1016/j.cities.2019.01.029

19. IECE. (2020). IECE Cities in Motion Index. Retrieved from https:// blog.iese.edu/cities-challengesand-management/2020/10/27/ iese-cities-in-motion-index-2020

20. IMD. (2020). IMD Smart City Index. Retrieved from https://www. 
imd.org/wcc/world-competitiveness-center-rankings/smart-cityindex-2020.

21. Jong, M., Joss, S., Schraven, D., Zhan, C., \& Weijnen, M. (2015). Sustainable-smart-resilient-low carbon-eco-knowledge cities; making sense of a multitude of concepts promoting sustainable urbanization. Journal of Cleaner Production, 109, 25-38. https://doi. org/10.1016/j.jclepro.2015.02.004

22. Knaap, G., \& Talen, E. (2005) New urbanism and smart growth: a few words from the academy. International Regional Science Review, 28(2), 107-118. https://doi. org/10.1177/0160017604273621

23. Komninos, N., Bratsas, C., Kakderi, C., \& Tsarchopoulos, P. (2015). Smart City Ontologies: Improving the Effectiveness of Smart City Applications. Journal of Smart Cities, 1(1), 31-46. Retrieved from https://www.udspub. com/ajj/public/index.php/jsc/ article/view/54

24. Korepanov, O. (2018). Metodolohichni zasady statystychnoho zabezpechennia upravlinnia rozvytkom "rozumnykh" stalykh mist $v$ Ukraini [Methodological bases of statistical support of management of development of "smart" sustainable cities in Ukraine]. National Academy of Statistics, Accounting and Audit. (In Ukrainian). Retrieved from http://nasoa.edu. ua/wp-content/uploads/zah/ korepanov_o_dis.pdf

25. Kummitha, R. K. R., \& Crutzen N. (2017). How do we understand smart cities? An evolutionary perspective. Cities, 67, 43-52. https://doi.org/10.1016/j.cities.2017.04.010

26. Kyiv Smart City Forum. (2020). Na Kyiv Smart City Forum 2020 provely shchorichnu tseremoniiu nahorodzhennia Smart City Awards [Annual Ceremony Smart City Awards was conducted during Kyiv Smart City Forum 2020]. (In Ukrainian). Retrieved from https://www.kyivsmartcity.com/ news/na-kyiv-smart-city-forum2020-proveli-shhorichnu-ceremoniyu-nagorodzhennya-smartcity-awards/
27. Lombardi, P., Giordano, S., Farouh H., \& Yousef, W. (2012). Modelling the smart city performance. Innovation: The European Journal of Social Science Research, 25(2), 137-149. https://doi.org/10.1080/1 3511610.2012 .660325

28. Luque-Ayala, A. \& Marvin, S. (2015). Developing a critical understanding of smart urbanism? Urban Studies, 52(12), 2105-2116. https://doi. org/10.1177/0042098015577319

29. Masik, G., \& Studzińska D. (2018). Ewolucja koncepcji i badania miasta inteligentnego = Evolution of the Smart City concept and of research into it. Przeglad Geograficzny, 90(4), 557-571. (In Polish). https://doi.org/10.7163/ PrzG.2018.4.2

30. Matyushenko, I., \& Pozdnyakova, A. (2016). Smart Cities in Ukraine - the evolution, state and challenges of smart solutions in the area of governance. Acta Innovations, 19, 25-36. Retrieved from https:// www.ceeol.com/search/articledetail $? \mathrm{id}=612854$

31. McFarlane, C., \& Söderström, O. (2017). On alternative smart cities: from a technology-intensive to a knowledge-intensive smart urbanism. City, 21(3-4), 312-328. https://doi.org/10.1080/13604813. 2017.1327166

32. Neirotti, P., De Marco, A., Cagliano, A.C., Mangano, G., \& Scorrano, F. (2014). Current trends in Smart City initiatives: Some stylised facts. Cities, 38, 25-36. https://doi.org/10.1016/j. cities.2013.12.010

33. OECD. (2020). Smart Cities and Inclusive Growth. Building on the outcomes of the 1st OECD Roundtable on Smart Cities and Inclusive Growth. Retrieved from http://www.oecd.org/cfe/cities/ OECD_Policy_Paper_Smart_Cities_and_Inclusive_Growth.pdf

34. Pavlikha, N., \& Kolomechiuk, V. (2018). Patterns and dynamics of the Formation of smart cities in the world and in Ukraine. Economic Journal of the Lesya Ukrainka Volyn National University, 2(14), 42-47. https://doi. org/10.29038/2411-4014-201802-42-47
35. Pilarczyk, A., \& Górka, K. (2018). Miasto Lublin jako smart city (Lublin as a smart city). In P. Maleszyk \& M. Sagan (Eds.), Lublin 2030 - europejska metropolia? Lublin: Urząd miasta Lublin, 147-159. (In Polish).

36. Poliakova, O., \& Pozdniakova, A. (2019). A methodological approach to evaluating the progress of the implementation of the smart city concept in Ukrainian cities. The Problems of Economy, 1(39), 73-82. https://doi. org/10.32983/2222-0712-2019-174-82

37. Pozdniakova, A. (2017). Digitalization process in Ukraine as a prerequisite for the smart city concept development. Baltic Journal of Economic Studies, 3(4), 206-215. https://doi.org/10.30525/22560742/2017-3-4-206-215

38. Pozdniakova, A. (2018). Smart city strategies "London-Stockholm-Vienna-Kyiv": in search of common ground and best practices. Acta Innovations, 27, 31-45. https:// doi.org/10.32933/ActaInnovations.27.4

39. Rosati, U., \& Conti, S. (2016). What is a smart city project? An urban model or a corporate business plan? Procedia-Social and Behavioral Sciences, 223, 968-973. Retrieved from https://core.ac.uk/ download/pdf/82436357.pdf

40. Sigalat-Signes, E., Calvo-Palomares, R., Roig-Merino, B., \& García-Adán, I. (2019). Transition towards a tourist innovation model: The smart tourism destination Reality or territorial marketing? Journal of Innovation \& Knowledge, 5(2), 96-104. https:// doi.org/10.1016/j.jik.2019.06.002

41. Smart city. (2020). Smart city. AllUkrainian platform of e-government and democracy. Retrieved from https://rozumnemisto.org

42. State Statistics Service of Ukraine. (2021). Main Statistical Office of Lviv Region. Retrieved from https://www.lv.ukrstat.gov.ua/eng/ engl.php

43. Transparency International Ukraine. (2018). Out now: 2018 transparency ranking of $100 \mathrm{Ukrai}$ - 
nian cities. Retrieved from https:// ti-ukraine.org/en/news/out-now2018-transparency-ranking-of100-ukrainian-cities/

44. Transparency International Ukraine. (2019). Transparency ranking of the 100 largest cities in Ukraine 2019. Retrieved from https://ti-ukraine.org/research/ rejtyng-prozorosti-100-najbilshyhmist-ukrayiny-2019

45. Vanolo, A. (2016). Is there anybody out there? The place and role of citizens in tomorrow's smart cities. Futures, 82, 26-36. https://doi.org/10.1016/j.futures.2016.05.010

46. Viitanen, J., \& Kingston, R. (2014). Smart Cities and Green Growth: Outsourcing Democratic and Environmental Resilience to the Global Technology Sector. Environment and Planning A: Economy and Space, 46(4), 803-819. https:// doi.org/10.1068/a46242

47. Winkowska, J., Szpilko, D., \& Pejić, S. (2019). Smart city concept in the light of the literature review.
Engineering Management in Production and Services, 11(2), 70-86. https://doi.org/10.2478/emj-20190012

48. Zakrzewska-Półtorak, A. (2016). Inteligentne miasto katalizatorem rozwoju regionu? [Smart city - is it a catalyst for regional development?]. Prace Naukowe Uniwersytetu Ekonomicznego we Wrocławiu - Research Papers of Wrocław University of Economics, 443, 283-291. (In Polish). https:// doi.org/10.15611/pn.2016.443.23 